\title{
On Black Feminism in The Help
}

\author{
HOU Xia
}

Zhoukou Normal University, Henan, China 466000

\begin{abstract}
The Help is regarded as one of the representative works reflecting the life of black women in the 21st century in the United States. It takes the real events in history as its material, and adds fictional characters and plots to express the author's thoughts on the social status of black women and the social problems. In terms of class, race, and gender, the author finds that the plight of black women is constantly repeating and they are still living at the bottom of society. From the perspectives of class oppression, racial discrimination, and gender discrimination, this paper explores the marginalized living conditions of black women in the United States and their spiritual salvation, thus analyzes the Black Feminism reflected in The Help.
\end{abstract}

Keywords: The Help, Black Feminism, gender discrimination, racial discrimination

\section{Introduction}

The 20th century is an era of great prosperity of cultural criticism theory schools. With the second climax of the western women's liberation movement, Feminist Criticism theory has sprung up. Women in the West are oppressed and excluded by men in almost every aspects , such as family, law, politics, and education, etc. They hope that women should strive for equal status and rights with men, explore and establish women's own literary classics and cultural traditions that have been drowned by patriarchal culture for a long time, and advocate the development of a kind of female poetry and the construction of a set of female criticism. Feminism integrates other trends of thought and literary criticism, and derives many branches. In the 1970s, Black Feminism emerged as a social and political movement. It believes that gender discrimination, class oppression, and racial oppression are intertwined, which makes "the oppression experienced by black women is different from that experienced by white women” (Cheng \& Fang, 2011, p. 37). Black women are in a crossed position. They not only endure discrimination of the whites against the blacks, but also bear violence against them by black men as members of disadvantaged black groups. All kinds of oppressive systems are interlocking, forcing black women to live at the bottom of society. Black women urgently need to build their own identity and gain respect and voice. The emergence of this trend of thought marked a new realm of racial and ethnic outlook in human society.

African-Americans account for a large proportion of American society. With the development of history, although their lives have been greatly improved for a long time, the discrimination and oppression of African-Americans by white people still remains. African Americans have seek equality and freedom since the 1950s, and a large number of black movements began to emerge. Since then, the social status and economic level of black people have been improved significantly. On this basis, in the early 21st century, Kathryn Stockett, an 
American female writer, published The Help, a novel reflecting the life of black women in the South of America. It tells of racial and gender discrimination in Jackson City, Mississippi, in the early 1960s, when the affirmative movement led by Dr. Martin Luther King was active. In society, the status of white men is high, while white women are dependencies of life, and colored people are untouchables who are trodden on the feet of the whites. In the book, the confrontation between the whites and black female servants is described as a blood-and-tear complaint of class oppression, racial discrimination, and gender discrimination.

\section{Class Oppression on Black Women by White People}

In this novel, most black women have to work as maids for white families in order to make a living. As the working people at the bottom of the society, they should be cautious in everything and not provoke white masters. In Jackson City, Minnie, a 40-year-old black woman, is the best cook, diligent and competent. No one wants to wipe more than two meters high floor windows, but she does. However, even so, no one wants to hire her. When she was very young, her mother taught her to abide by the rules of dealing with white people. Don't treat white people as friends; work for white people as invisible people, and treat yourself as non-existent; use a set of tableware alone and tell white wives that they have been put aside; eat in the kitchen; and don't teach white children. The most important thing is never answering back. If you talk back to the white lady in the morning, you'll be kicked out at noon. Minnie is hard to do all of these. When she did her first job as washing clothes, the white lady ordered her to clean her hands first. She asked her master in a very naive way, "Is this not a superfluous act”? The lady fired her immediately in the afternoon. Later Minnie took care of a white old lady who was half deaf. It was the longest job she had ever done. However, the old lady's daughter, Miss Hilly, could not tolerate such a disobedient servant. Sending the old lady to a nursing home and spreading Minnie's stealing everywhere made Minnie unable to find another job any more.

In fact, from the book, we can see that Minnie wants to get rid of the white people's oppression from her heart, and she has the desire to express her ideas and hopes to gain a certain voice. However, Minnie's daughter had to drop out of school to work for the white people to pay the bills because of her hard life. Before sending her daughter to the white house, Minnie taught the "maid's way" like her mother. When serving coffee to white people, you can't pass it to them, but put it in front of them, because you can't touch their hands; you can't discipline white children; you can't answer back! We see Minnie carries her mother's thinking. She not only teaches her daughter how to serve the white people, but also tells her to be tolerant and compromise to everyting. She seems to have convinced herself that white people are the black people's masters.

Later, the appearance of the white woman Skeet prompted the black maids to struggle against the adversity and submission of life. Skeeter tried to interview black maids, and when she found herself capable of acting as an editor, she stood with them to expose the bitterness of their work and life to society. Minnie, encouraged by her, spoke out bravely about her experiences and her true thoughts. Later, the sister of the black maid Aibileen was burnt down by complaining about the white people. Then Minnie put manure into the cake to revenge Miss Hilly, and maddened the arrogant white lady. Miss Hilly then accused Minnie of stealing, which made everyone in the town afraid to hire her. Minnie had hardly any source of livelihood since then. In fact, Miss Hilly grew up under Minnie's careful care. After she got married, Minnie became her maid again. However, she was irascible and mean, and had no gratitude or respect for Minnie. She even sat on the toilet paper to prevent blacks from taking 
advantage of herself. In fact, black people also have principles and dignity. Toilet paper is brought from home. The loyalty, tolerance, and dedication of the maid contrasts sharply with the ruthlessness and selfishness of the white people.

\section{Racial Discrimination Against Black Women by White People}

Aibileen, a 60-year-old maid, brought up 17 children of the whites' families. Almost all black maids devote most of their lives to a white family, while Abilene changes jobs before her children become sensible. She didn't want to see every child she brought out hardly grow up to be the same as their parents, so she always asked to leave before they knew the difference between the blacks and the whites. Her own son died on the way home because of the negligence of the white boss. Something collapsed in Aibileen's heart, but she did not have the right to be in grief all the time. In order to make a living, she could only hide her grief and begin to take care of the girl May. She had to take good care of her master's children when she was suffering from the loss of her son, and also remained silent all the time. Even if she is insulted in public, she should also turn a deaf ear, turn a blind eye, and go on the housework silently.

Black women, who act as housekeepers and cooks for white middle-class ladies, are constantly subjected to irony and criticism, but in order to survive, they have repeatedly chosen to bear all the biases, even deprived of the right to share toilets with white people. They have developed tremendous fears of white people and shown almost numb compromises to racial discrimination. For example, the conversation between Aibileen's hostess and her friends is about whether black servants and white people can share the bathroom. Miss Hilly, the wife of the congressman, said that blacks carried germs and could not use the toilet with them in order to avoid being infected. She tried to persuade Mrs. Riverold to set up a special bathroom for the black maid in the yard. The next day, the hostess did invite someone to build a servant's toilet outside the house. Aibileen felt great pain in her heart, but she remained silent. Later, however, the host angrily blamed his wife of wasting her daughter May's money which is prepared for May to go to college in the future. Aibileen, huddled in the corner, could do nothing but open her arms and embrace May, who was in shock and crying. She would always be silent. The world around her had shown that it would be worse and worse in the future.

The sympathy for her own sufferings and the humiliation of her companions inspired Aibileen's courage. The kind-hearted Aibileen realized that only by standing up could she protect the tens of millions of black maids behind her and claim a little dignity from the society. In fact, they did not resist maliciously; they just expressed their experiences and perceptions to the world through Miss Skeet's book. The racial issues reflected in this book have aroused social repercussions, and many people were awakened to fight for equal rights for people. Aibileen and Minnie used their words and actions to help black maids to fight against discrimination and oppression, and they were recognized and respected by everyone. More and more black women joined the campaign without fear of retaliation and resisted bravely. The most touching thing is that even though white employers are deeply disgusted, black maids still conveyed goodwill to the white children they cared for. "You are kind, you are smart, you are important”. This is what the black maid Aibileen said to the little white girl she looked after everyday. She also bravely pointed out the mistakes of racial discrimination to the child, and did not want to see her growing up affected by racial bias. 


\section{Gender Discrimination Against Black Women by Black Men}

"Black men may be victims of racial discrimination, but gender discrimination makes them exploiters and oppressors of women” (Hooks, 2001, p. 19). Neither white nor black men can deeply appreciate the inhuman suffering of black women. Beauvoir first expounded the concept of female otherness in the feminist "Bible”, Second Sex. It contains four meanings:

Men are autonomous people, women are not autonomous people; the reference for defining and distinguishing women is men, while the reference for defining and distinguishing men is not women; women, as men, are mainly sexual beings, to him she is sex; women are dependent people, and are the minor opposite to the main ones. (Beauvoir, 2004, p. 4)

It can be seen that women are lower than men, not born like this, but kidnapped by the collective consciousness of society. In patriarchal society, black women are certainly no exception. In American history, black women in the United States suffered racial discrimination from white people and gender discrimination from black patriarchal society. If black women want to get rights and freedoms in the crack, they must confront to both of them. Minnie, the black maid in the book, started from her own experience, ponders and explores deeply, expressing her dissatisfaction with the encounter and oppression from the perspective of black women.

Minnie, with excellent grades and intelligent mind, is considered to be one of the few black children who has the hope of finding jobs outside the white population. Minnie dropped out of school on her 14th birthday, in order to keep her sister with heart disease alive, and to keep her drunk father from going mad. "In Mississippi in the 1960s, racial discrimination was so serious that black men could not assume the role of improving their economy and supporting their families as men, instead turning their depression and discontent to the weaker female groups” (Zhang, 2012, p. 163). Minnie not only suffered from discrimination and revenge at work, but also endured abuse and beatings from drunkard husbands all day long in her life. As for her, she should be careful when she comes home, and be glad to avoid her husband's beating every time. Her husband would not beat her during pregnancy, so Minnie kept getting pregnant to escape her husband's domestic violence. She even hoped that the children in her stomach would become amulets. The black women had a dreary life. In retaliation for Minnie’s participation in the book The Help, Miss Hilly ordered Minnie’s husband to leave. After that, he wanted to kill Minnie, causing her bleeding and homeless. Weak Minnie chose to endure it silently, as if this was the safest way to protect herself. However, it could not change life, it may only push Minnie to the edge of fate step by step. But after experiencing domestic violence and torture, Minnie finally summoned up the courage to take her children away from her husband who brought her physical and mental suffering, and started a new life. Minnie gradually realized that women were not subordinate to men's existence and could get rid of the shackles of family and became an economically and ideologically independent woman. She clearly realized that women's tragic fate was caused by the traditional consciousness of patriarchal society, and women's humility was due to their dependence on men. Therefore, they could not be subjected to social oppression, and they could not always obey men's arrangements, or even silently endure domestic violence. She gradually learned how important it was to be a woman who learned to resist and to be independent. Minnie eventually transformed from a humble woman who silently tolerated unfair treatment to a woman who had the sense of independence and self-control in the new era of her life. 


\section{Conclusion}

Before the 20th century, black American women experienced various oppressions from the American social environment including black men. Many modern American female novelists are exploring ways of self-salvation of black women. The attitude of black women towards oppression in the novel has changed from passive evasion to positive resistance, which fundamentally liberates their thoughts. If black women want to achieve equality and freedom, they must break the shackles of thought through their own efforts. At the end of the book, Aibileen and Minnie finally decided to publish anonymous books with Skeeter about their life experiences. Customized to silence, they can not find the right words to express their long-suppressed emotions. Each step to break the routine behind the accumulation is filled with more courage. But who can benefit from this change? Is there only double suffering for the weak when they speak? Writing is the only salvation that these three women can think of. It also marks the beginning of black women's struggle for equal rights in their own words. This novel is not simply about racial discrimination, but also shows social injustice suffered by black women. It hopes to present the experiences, choices, feelings, and real personality of black maids in such a social environment. Some of them are weak, some are humble, some are stubborn, but their charm of personality is strong, optimistic, and brave. Faced with oppression, they did not always escape from life with a victim's attitude and did not feel resentment. Instead, they traveled with a calm and self-restrained attitude and fate reconciled with life, redeemed themselves, and faced up to their thirst for respect. This kind gesture sublimates the souls of the maids from "fighting evil with evil" to "stimulating good with good". As the title of the card shows-The Help, Kindness helps them to support each other and help each other so that these brave women can finally fight a beautiful battle toward class oppression, racial discrimination, and gender discrimination. The Help not only presents the resistance to the unfair treatment toward black females in America, but also their seek of identity, respect, and even the meaning of life, which is the essence of Black Feminism.

\section{References}

程锡麟\&方亚中 (2011). 什么是女性主义批评、上海: 上海外语教育出版社. 贝尔・胡克斯. (2001). 女权主义理论: 从边缘到中心. 晓征等译. 南京: 江苏人民出版社. 西蒙娜·德·波伏娃. (2004). 第二性. 陶铁柱译. 北京: 中国书籍出版社. 张琳娜. (2012). The Help 小说中黑人女佣们的宿命到觉醒之路. 时代文学, 8, 163-164. 周珊. (2004). 白人主导文化下黑人女性两种响应之对比. 合肥: 安徽大学. 傅兴丽. (2011) 黑人女性的觉醒之旅. 长春: 吉林大学. 